\title{
Oral P. gingivalis infection alters the vascular reactivity in healthy and spontaneously atherosclerotic mice
}

\author{
Raquel B Pereira*, Elisardo C Vasquez, Ivanita Stefanon and Silvana S Meyrelles
}

\begin{abstract}
Background: Considering that recent studies have demonstrated endothelial dysfunction in subjects with periodontitis and that there is no information about vascular function in coexistence of periodontitis and atherosclerosis, we assessed the impact of oral inoculation with the periodontal pathogen Porphyromonas gingivalis on vascular reactivity in healthy and hypercholesterolemic apolipoprotein E-deficient (ApoE) mice. In vitro preparations of mesenteric arteriolar bed were used to determine the vascular responses to acetylcholine, sodium nitroprusside and phenylephrine (PE).

Results: Alveolar bone resorption, an evidence of periodontitis, was assessed and confirmed in all infected mice. Acetylcholine- and sodium nitroprusside-induced vasorelaxations were similar among all groups. Non-infected ApoE mice were hyperreactive to PE when compared to non-infected healthy mice. $P$ gingivalis infection significantly enhanced the vasoconstriction to PE in both healthy and spontaneous atherosclerotic mice, when compared to their respective controls.

Conclusions: This study demonstrates that oral $P$ gingivalis affects the alpha-adrenoceptor-mediated vascular responsiveness in both healthy and spontaneous atherosclerotic mice, reinforcing the association between periodontitis and cardiovascular diseases.
\end{abstract}

\section{Background}

Periodontal disease is a chronic inflammatory disease that affects the gum tissue and other structures supporting the teeth. It begins as gingivitis and, if left untreated, can progress to periodontitis, where destruction of connective tissue attachment and alveolar bone can lead to tooth loss. Beyond its local effects, periodontal disease may also interfere with other systems of the body, and many epidemiological studies have associated periodontitis with atherosclerosis. However, a causal relation between both diseases remains controversial [1].

Investigators have proposed that periodic transient bacteremia, which leads to invasion of vascular cells and increase of the levels of circulating cytokines, accelerates the atherogenic process [2]. Also, it has been reported

\footnotetext{
* Correspondence: raquelbinda@yahoo.com.br

Department of Physiological Sciences, Health Sciences Center, Federal University of Espirito Santo, Vitoria, ES, Brazil
}

that $P$ gingivalis, the periodontopathogen associated with the most common form of periodontal disease, accelerates atheroma formation [3-5], increases systemic inflammatory markers [4,6-8], invades endothelium and vascular smooth muscle cells $[9,10]$ and appears to alter endothelial function [11-15].

Endothelial dysfunction appears to be an early event in the development of atherosclerosis [16] and also predicts plaque instability [17]. Support for the clinical importance of vascular reactivity and endothelial dysfunction is provided by several studies demonstrating increased cardiovascular disease risk in patients with vascular dysfunction in coronary and peripheral arteries [17-22].

On the basis of these observations, we aim to investigate whether oral $P$ gingivalis infection alters the vascular responsiveness in spontaneous atherosclerosis in apolipoprotein E-deficient (ApoE) mice compared with C57BL/6 (C57) wild-type mice.

C Biomed Central

(c) 2011 Pereira et al; licensee BioMed Central Ltd. This is an Open Access article distributed under the terms of the Creative Commons Attribution License (http://creativecommons.org/licenses/by/2.0), which permits unrestricted use, distribution, and reproduction in any medium, provided the original work is properly cited. 


\section{Methods}

\section{Experimental groups}

Experiments were conducted on adult (30-week-old) male C57 and ApoE mice from the Laboratory of Transgenes and Cardiovascular Control of the Federal University of Espirito Santo. Animal care and treatment were approved by the institutional Ethics Committee for Use of Animals (CEUA-Emescam, Protocol \# 020/2007) and were conducted in conformity with institutional guidelines, in compliance with international laws and policies. C57 mice were used as animals systemically healthy. C57 and ApoE animals were randomly divided in control $(\mathrm{Ct})$ or infected $(\mathrm{Pg})$ groups: C57 Ct, C57 Pg, ApoE Ct, ApoE Pg.

\section{Preparation of bacterial culture and oral infection}

$P$ gingivalis strain ATCC 33277 was obtained from the Collection of Microorganisms of Reference (INCQS, Fiocruz, Brazil) and cultured in blood-agar supplemented with hemin/menadione, under an anaerobic condition [23]. At age of 18 weeks randomly selected mice were infected with $P$ gingivalis as follows. $10^{9} \mathrm{CFU}$ of live bacteria (optical density of $\approx 0.8$ at $660 \mathrm{~nm}$ ) in $100 \mu \mathrm{L}$ of PBS with $2 \%$ carboxymethylcellulose was administered via oral topical application three times at 2-day intervals. Control mice received carboxymethylcellulose in PBS. Infected mice were kept in microisolated cages (Beiramar, Brazil).

\section{Cholesterol and systemic inflammation analysis}

At 30 weeks of age, under anesthesia with thiopental (40 $\mathrm{mg} / \mathrm{kg}$ i.p.), mice were subjected to the axillary plexus isolation and samples of blood were obtained by punction [24]. For each mouse two blood samples were collected. Serum was obtained to determine the levels of plasma total cholesterol by chromogenic assays (Bioclin, Brazil). Blood was used to perform leucogram (Beckman Coulter MAXM HMX, USA). Systemic host inflammatory response or systemic inflammation was assessed by neutrophils/lymphocytes ratio [25].

\section{"In Vitro" preparation of the mesenteric arteriolar bed}

Isolated mesenteric arteriolar beds were obtained 12 weeks after $P$ gingivalis inoculation of the animals and after blood samples collection. Briefly, the superior mesenteric artery was cannulated (PE 50, Becton Dickinson, Sparks, MD, USA), and the intestine was immediately severed from the body. The mesenteric vascular bed was perfused at a constant flow of $2 \mathrm{~mL} / \mathrm{min}$ with oxygenated (mixture of $95 \% \mathrm{O}_{2}$ and $5 \% \mathrm{CO}_{2}, 37^{\circ} \mathrm{C}$ ) physiological salt solution (130 NaCl, $4.7 \mathrm{KCl}, 1.6$ $\mathrm{CaCl}_{2} \circ 2 \mathrm{H}_{2} \mathrm{O}, 1.8 \mathrm{KH}_{2} \mathrm{PO}_{4}, 4.7 \mathrm{MgSO}, 1.17 \mathrm{H}_{2} \mathrm{O}, 14.9$ $\mathrm{NaHCO}_{3}, 0.026$ EDTA, and 11.1 glucose; mmol/L), using a roller pump (Harvard Apparatus, USA). The bowel was removed to prevent the return of the Krebs' solution through the venous system. After passing through the vascular bed, the perfusate was artificially drained out from the preparation. After a 40-min stabilization period, the experimental protocol was initiated. Mean perfusion pressure (MPP) was measured; as a result of maintenance of a constant flow, changes in the MPP represented changes in vascular resistance. The vasoconstrictor response was assessed by stimulation of $\alpha$-adrenoceptors evoked by phenylephrine (PE; 0.001 $300 \mu$ g; Sigma-Aldrich). To study endothelium-dependent and endothelium-independent vasodilation, responses to acetylcholine (ACh; $10^{-10}$ to $10^{-3} \mathrm{~mol} / \mathrm{L}$; Sigma-Aldrich) and sodium nitroprusside (SNP; $10^{-10}$ to $10^{-3} \mathrm{~mol} / \mathrm{L}$; Sigma-Aldrich) respectively were determined as percentages of reductions in the precontractions induced by $10^{-5} \mathrm{~mol} / \mathrm{L} \mathrm{PE}$ (concentration that induces $60 \%$ to $80 \%$ of the maximal effect).

\section{Quantification of atherosclerotic lesion area}

After bowel removal the heart was perfused through right atrium with $50 \mathrm{~mL}$ of PBS (0.1 M; pH 7.4), following by $50 \mathrm{~mL}$ of formaldehyde (4\%). Aorta was removed and stored in buffered fixative solution, and cryostat sections were prepared, as previously described [26]. Atherosclerotic lesion area was quantified using a microscope (Olympus, Japan) interfaced with a videocamera (Hitachi, Japan) and an image analysis system (Image J, USA). Mean lesion area per mouse was calculated by an investigator blinded to the experimental protocol and was expressed as $\mu \mathrm{m}^{2}$.

\section{Quantification of alveolar bone loss}

Alveolar bone between first and second molars of the left mandible was assessed by a morphometric method. Briefly, after 15 minutes in boiling water mandible was mechanically defleshed, exposed overnight in 3\% hydrogen peroxide and immersed in bleach for 1 minute. The bone level, that is, the distance from the cementumenamel junction $(\mathrm{CEJ})$ to the alveolar bone crest $(\mathrm{ABC})$ was measured under a dissecting microscope $(\times 40)$ with a total of 2 measurements per mouse. The measurements were repeated two times per site in random and blinded protocols. Because a greater distance from the CEJ-ABC indicates less alveolar bone, bone levels were converted to relative amounts of bone by the following calculation: 1/distance from CEJ-ABC [23]. The values were normalized by converting bone values of each mouse to a percentage of the mean value for respective control mice group.

\section{Statistical Analysis}

Vascular responses are given as percentage of dilation relative to the PE-induced preconstriction level. Values 
are expressed as means \pm SEM. For each dose-response curve, the maximum effect $\left(E_{\max }\right)$ and the dose of agonist that produced one-half of $E_{\max }\left(E_{50}\right)$ were estimated using nonlinear regression analysis (GraphPad Software Inc., San Diego, CA). The sensitivity of the agonists is expressed as $\mathrm{pED}_{50}$. One- and two-way ANOVA, followed by Bonferroni $t$ test, or unpaired Student's $t$ test when appropriated, were used for statistical analyses. $p<0.05$ was considered statistically significant.

\section{Results}

Alveolar bone loss produced by oral infection with $P$ gingivalis

To determine the degree of local periodontal destruction, we dissected the mandibles after euthanasia and measured alveolar bone loss. As summarized in Figure 1 , infected mice displayed significantly increased alveolar bone loss compared with the respective control, indicated by a decrease in relative amounts of bone in infected mice (C57 Ct; $100 \pm 2$ versus C57 Pg; $48 \pm 6 \%$; ApoE Ct: $103 \pm 6$ versus ApoE Pg: $63 \pm 2 \%$, respectively; $p<0.05$ for all comparisons).

\section{Effects of the oral $P$ gingivalis infection on serum} cholesterol levels and systemic inflammatory response We investigated if the oral infection with $P$ gingivalis modulated established risk factors for atherogenesis in this murine model. No differences in total plasma cholesterol were observed between infected and control groups in both C57 (Ct: $78 \pm 6$ versus Pg: $85 \pm 3 \mathrm{mg}$ / $\mathrm{dL})$ and ApoE groups (Ct: $523 \pm 64$ versus Pg: $629 \pm 41$ $\mathrm{mg} / \mathrm{dL}$ ) groups (Table 1$)$. When systemic inflammation was analyzed we observed an increase ( 3-fold) in

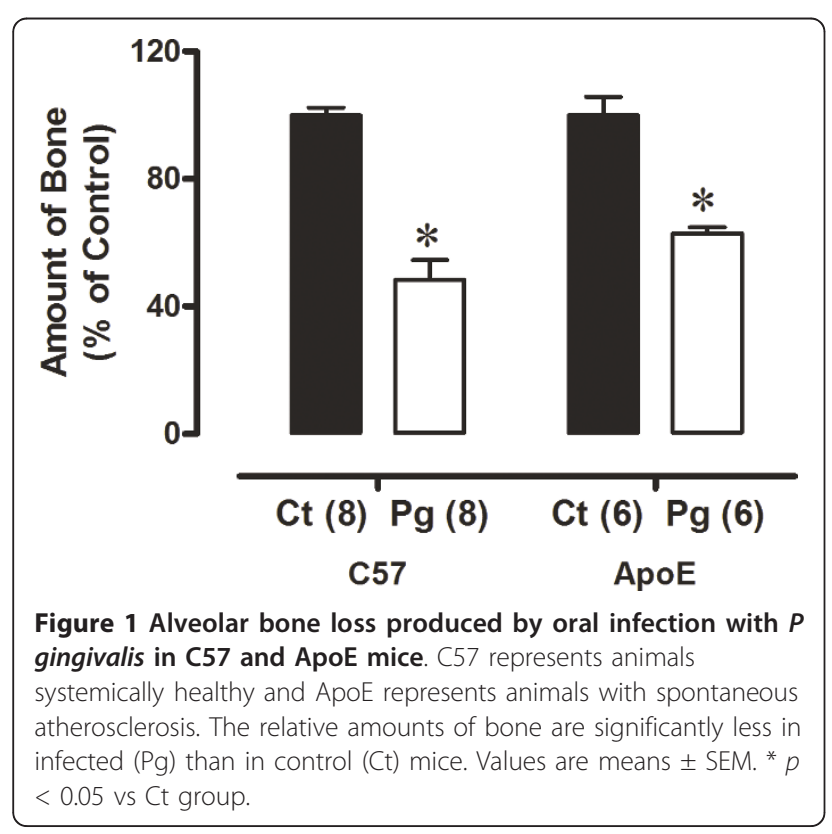

Table 1 Effects of Oral Infection with P gingivalis on Serum Cholesterol and Body Weight

\begin{tabular}{lcccc}
\hline Parameters & C57 Ct (8) & C57 Pg (8) & ApoE Ct (7) & ApoE Pg (6) \\
\hline Body weight (g) & $35 \pm 0.6$ & $33 \pm 0.6$ & $34 \pm 0.8$ & $33 \pm 1.5$ \\
$\begin{array}{l}\text { Serum cholesterol } \\
\text { (mg/dL) }\end{array}$ & $78 \pm 6$ & $85 \pm 3$ & $523 \pm 64^{\dagger}$ & $629 \pm 41^{\S}$ \\
\hline
\end{tabular}

Values are mean \pm SEM.

${ }^{+}$vs $\mathrm{C} 57 \mathrm{CT} ;{ }^{\S}$ vs $\mathrm{C} 57 \mathrm{Pg} ; p<0.05$.

neutrophils/lymphocytes ratio from mice with atherosclerosis compared to C57 in both control (ApoE: 0.17 \pm 0.01 versus C57: $0.06 \pm 0.01 ; p<0.05)$ and infected (ApoE: $0.17 \pm 0.02$ versus C57: $0.05 \pm 0.001 ; p<0.05$ ) animals (Figure 2). However, oral $P$ gingivalis inoculation did not change $(p>0.05)$ the systemic inflammatory status in both healthy and atherosclerotic mice, when compared to their controls (Figure 2). Body weight was also monitored and was similar among all groups (Table 1).

Effects of the oral $P$ gingivalis infection on atherosclerotic lesion area

To evaluate if the oral infection with $P$ gingivalis amends the progression of atherosclerotic lesions, morphometric analyses were used and demonstrated that there were no differences $(p>0.05)$ in mean atherosclerotic lesion area in infected mice compared with controls in both C57 (Pg: $0.75 \pm 0.2$ versus Ct: $0.66 \pm$ $0.2 \mu \mathrm{m}^{2} \times 10^{3}$ ) and ApoE (Pg: $57.5 \pm 4.3$ versus Ct: $41.25 \pm 0.9 \mu \mathrm{m}^{2} \times 10^{3}$ ) groups (Figure 3).

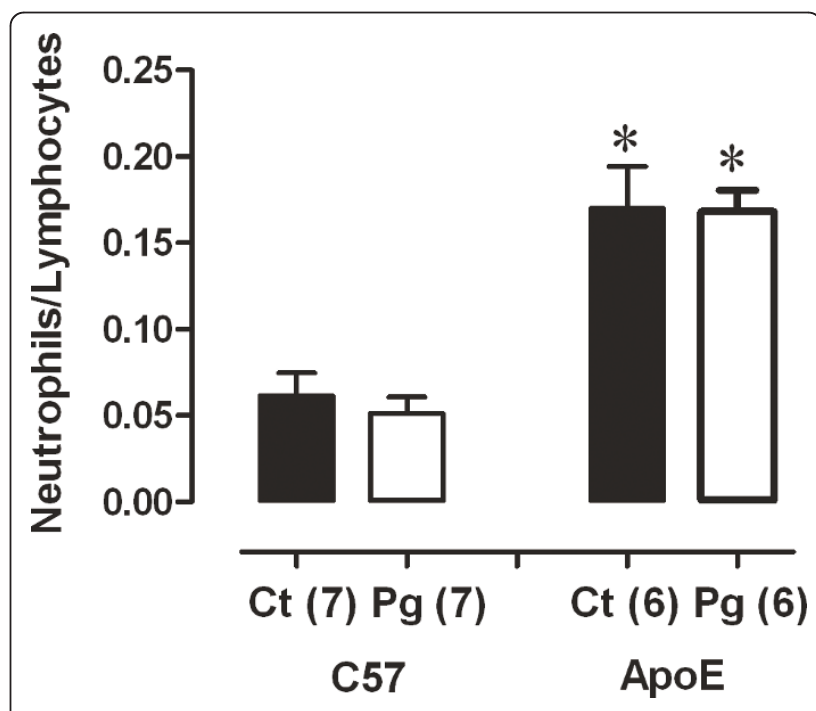

Figure 2 Oral $P$ gingivalis infection and systemic inflammation Atherosclerotic mice have increased neutrophils/lymphocytes ratio when compared to C57. Ct: control animals; Pg: infected animals. ${ }^{*} p$ $<0.05$ vs. C57. 


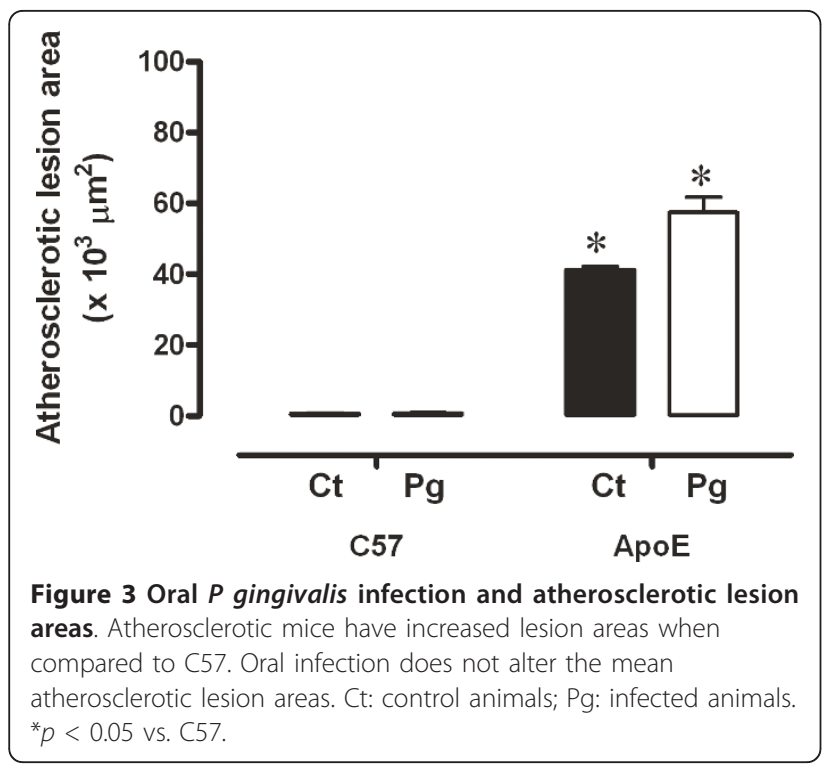

Effects of the oral $P$ gingivalis infection on mesenteric arteriolar bed responsiveness

We examined the effects of $P$ gingivalis oral infection on mesenteric arteriolar bed responsiveness to phenylephrine, acetylcholine and sodium nitroprusside. As summarized in Figure 4 (panel A) the spontaneous atherosclerotic mice were hyperreactive to phenylephrine when compared to systemically healthy mice (ApoE Ct: $98 \pm 5 \mathrm{mmHg}$ versus C57 Ct: $79 \pm 3 \mathrm{mmHg} ; p<$ $0.05)$. Periodontitis caused by $P$ gingivalis oral inoculation enhanced $(p<0.05)$ the maximal response to phenylephrine in all groups when compared to the respective control group in both C57 (Pg; $92 \pm 6$ versus Ct: $79 \pm 3 \mathrm{mmHg}$ ) and ApoE (Pg: $119 \pm 7$ versus Ct: 98 $\pm 5 \mathrm{mmHg}$ ) groups (Figure 4B and 4D). Figure 4 (panel D) shows the preservation of the vascular hyperreactivity to phenylephrine of atherosclerotic mice $(119 \pm 7$ $\mathrm{mmHg}$ ) compared to healthy mice $(92 \pm 6 \mathrm{mmHg} ; p<$ $0.05)$ even after $P$ gingivalis infection. Despite of changes in vasoconstrictor responses, neither endotheliumdependent nor endothelium-independent vasodilations were changed by $P$ gingivalis oral infection (values shown in Table 2).

\section{Discussion}

The present study was designed to test whether oral challenge with an established periodontal pathogen amends vascular responsiveness in a murine model of spontaneous atherosclerosis. Surprisingly, our data show that oral $P$ gingivalis infection not only increases the vascular contractile response to phenylephrine in atherosclerotic mice but also in systemically healthy mice. The ApoE model of atherosclerosis used in this study is well established $[27,28]$. In agreement with previous

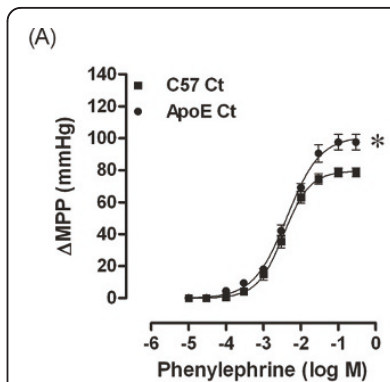

(B)

(C)

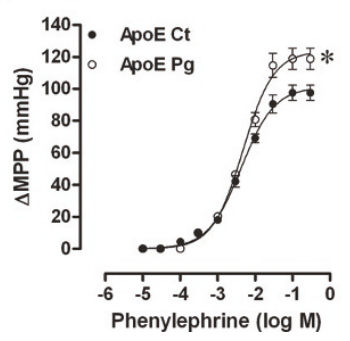

(D)
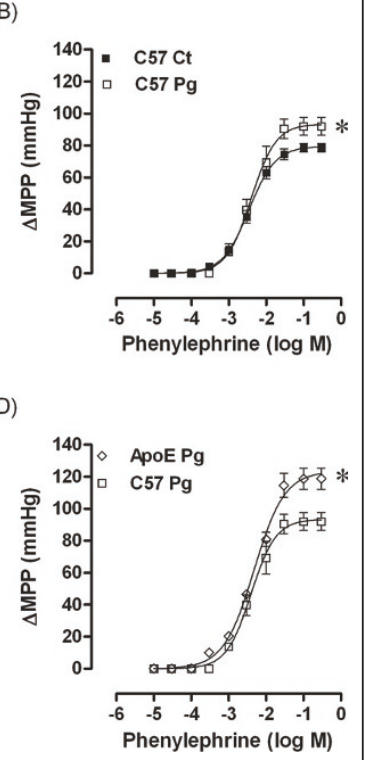

Figure 4 Phenylephrine dose-response curves in mesenteric arteries of C57 and ApoE mice, 12 weeks after $P$ gingivalis oral inoculation. A: Effect of atherosclerosis on vasoconstriction; B: Effects of oral infection on vascular contractile response in systemically healthy mice; C: Effects of oral infection on vascular contractile response in mice with atherosclerosis; D: Difference on vascular contractile response between animals systemically healthy and with atherosclerosis. Ct: control animals; Pg: infected animals. ${ }^{*} p$ $<0.05$.

studies we detected high levels of plasma cholesterol in ApoE mice fed a standard chow diet [28-31]. We also noted that the systemic inflammation observed in this study is consistent with the fact that atherosclerosis is a systemic inflammatory disease [32]. An important finding of this study is that oral $P$ gingivalis inoculation did not change the systemic inflammatory status in atherosclerosis, a result consistent with that described by

Table 2 Effects of Oral Infection with P gingivalis on Vascular Reactivity to PE, ACh and SNP

\begin{tabular}{|c|c|c|c|c|}
\hline Parameters & C57 Ct (8) & $\mathrm{C} 57 \mathrm{Pg}(8)$ & ApoE Ct (7) & ApoE Pg (6) \\
\hline \multicolumn{5}{|l|}{$\overline{P E}$} \\
\hline $\begin{array}{l}\mathrm{E}_{\max } \\
(\mathrm{mmHg})\end{array}$ & $79 \pm 2.7$ & $92 \pm 5.5^{*}$ & $98 \pm 5^{\dagger}$ & $119 \pm 7^{* \neq}$ \\
\hline $\mathrm{pED}_{50}$ & $2.5 \pm 0.09$ & $2.37 \pm 0.06$ & $2.40 \pm 0.07$ & $2.3 \pm 0.05$ \\
\hline \multicolumn{5}{|l|}{ ACh } \\
\hline $\begin{array}{l}\mathrm{E}_{\max }(\% \text { of } \\
\text { relaxation) }\end{array}$ & $76 \pm 2.3$ & $74.5 \pm 1.4$ & $75.5 \pm 2.9$ & $75 \pm 3$ \\
\hline $\mathrm{pED}_{50}$ & $6.15 \pm 0.17$ & $6.25 \pm 0.1$ & $6.12 \pm 0.27$ & $6 \pm 0.18$ \\
\hline \multicolumn{5}{|l|}{ SNP } \\
\hline $\begin{array}{l}\mathrm{E}_{\max }(\% \text { of } \\
\text { relaxation) }\end{array}$ & $92 \pm 1.3$ & $89 \pm 0.8$ & $91 \pm 2.5$ & $92 \pm 2$ \\
\hline $\mathrm{pED}_{50}$ & $6.6 \pm 0.07$ & $6.71 \pm 0.04$ & $6.90 \pm 0.10$ & $6.7 \pm 0.08$ \\
\hline
\end{tabular}

Values are mean \pm SEM.

${ }^{*} \mathrm{Pg}$ versus $\mathrm{Ct} ;{ }^{\dagger}$ versus $\mathrm{C} 57 \mathrm{Ct},{ }^{\ddagger}$ versus $\mathrm{C} 57 \mathrm{Pg} ; p<0.05$. 
Miyamoto et al. [33]. In healthy animals it was not detected systemic inflammatory response induced by oral $P$ gingivalis infection, although some authors have reported an increase in systemic inflammatory markers such as C-reactive protein, interleukin 6 and neutrophils in subjects with periodontitis [6-8]. Therefore, more studies are necessary to elucidate this controversial data. One consideration and limitation is that in the present study we investigated the effects of only one periodontal pathogen, while human periodontitis encloses several microorganisms.

The oral $P$ gingivalis infection did not influence the serum cholesterol levels. This result is in agreement with those found in mice infected with $P$ gingivalis [4] and humans [11] with periodontitis. Although literature reports an increase in the area of atherosclerotic lesion caused by $P$ gingivalis in animal models $[4,5,33,34]$, in this study we did not find changes in the atherosclerotic lesion area. We attribute this difference to different methodologies used in the studies. Li et al. [5] reported increase in the area of injury only after 14 intravenously weekly inoculations of $P$ gingivalis $\left(10^{7} \mathrm{CFU}\right)$ in atherosclerotic mice. Animals inoculated for 10 weeks did not show any change in the area of plaque [5]. In our study we performed only three inoculations, and to mimic normal conditions for which periodontal pathogens could reach the circulatory system, the inoculation of $P$ gingivalis was oral topical, and not intravenously as described by those authors. Lalla et al. [4] also observed increased aortic lesions in ApoE mice after 15 inoculations $\left(10^{12} \mathrm{CFU}\right)$ with $P$ gingivalis. Again, the number of inoculations in that study was high and was performed by oral gavage and anal topical application; the latter mode used to establish a cycle of oral reinfection, because mice use to be coprophagic. In the present study, however, the extent of the injury may not have changed because we used smaller burden of pathogens $\left(10^{9} \mathrm{CFU}\right)$, the inoculations were less sparse and smaller in number, and because we used only oral topical inoculation, that is more compatible with periodontitis in humans. Despite of a great difficulty in establishing a model of periodontitis similar to periodontal disease in humans, $P$ gingivalis inoculation reproduces the periodontal tissue destruction found in humans, making this model well accepted to study periodontitis.

Endothelial dysfunction has been considered one of the early steps in atherosclerosis [32]. Although endothelial dysfunction has been frequently considered when an impaired endothelium-dependent vasodilation is observed, the localized modulation of vascular endothelium to a nonadaptive functional state can be termed as endothelial dysfunction [35]. In ApoE mice, endothelial dysfunction, taken as an impaired endothelium-dependent dilation, is controversial. Endothelial dysfunction can be detected or not in ApoE mice depending on the type of diet, age, gender, and type of vessel [36-45]. Recently it was shown in the mesenteric vascular bed from male ApoE mice vascular dysfunction, characterized by increased pressor responsiveness to norepinephrine, despite of normal endothelium-dependent and -independent relaxations [44]. Similarly, we observed a hyperreactive response to phenylephrine in atherosclerotic animals without changes in endotheliumdependent and -independent vasodilations to acetylcholine and sodium nitroprusside, respectively. At present, the mechanism by which hypercholesterolemia alters vascular responsiveness in mesenteric arteriolar bed is unknown and further studies will try to elucidate this issue.

Interestingly, the hyperreactivity to the $\alpha$-adrenoceptor agonist in ApoE mice infected with $P$ gingivalis was exacerbated when compared with noninfected ApoE animals. In the systemically healthy mice, the response to phenylephrine was also increased, but if we compare its maximal responses, the hyperreactivity was more pronounced in ApoE mice. The mechanism by which oral $P$ gingivalis infection interferes with the reactivity to phenylephrine is unknown. However, based on the finding of an increased production of endothelin in crevicular fluid in subjects with periodontitis [46] and that the actions of endothelin include cell proliferation, migration and contraction [47], we speculate that one of the possible mechanisms by which periodontitis leads to exacerbated pressor response to $\alpha$-adrenoceptor agonists could be the increase of systemic levels of endothelin.

\section{Conclusions}

In conclusion, in the present study we demonstrate that oral $P$ gingivalis infection amplifies the vasoconstrictor hyperreactivity to phenylephrine in mice with spontaneous atherosclerosis. Moreover, in healthy mice the oral $P$ gingivalis infection also produces increased vasoconstrictor response to this $\alpha$-adrenoceptor agonist. This finding supports the hypothesis that oral infection with $P$ gingivalis is one of several risk factors of cardiovascular diseases.

\section{Acknowledgements}

We thank J P L Damasceno for expert technical assistance in histology. This research was supported by the National Council for the Development of Science and Technology (CNPq) and State Agency for the Development of Science and Technology (FAPES: PRONEX 012/2009).

\section{Authors' contributions}

RBP conceived the study, carried out the animal experiments, analysis of data, statistics and drafted the manuscript. ECV and IS participated in the Cosupervision of the study and in the critical revision of the manuscript. SSM participated in design and supervision and in the critical revision of the manuscript. All authors read and approved the final manuscript. 


\section{Competing interests}

The authors declare that they have no competing interests.

Received: 26 March 2011 Accepted: 17 May 2011

Published: 17 May 2011

\section{References}

1. Beck JD, Offenbacher S: Systemic effects of periodontitis: epidemiology of periodontal disease and cardiovascular disease. J Periodontol 2005, 76:2089-2100.

2. Libby $P$, Ridker PM, Maseri A: Inflammation and atherosclerosis. Circulation 2002, 105:1135-1143

3. Gibson FC, Hong C, Chou HH, Yumoto H, Chen J, Lien E, Wong J, Genco CA: Innate immune recognition of invasive bacteria accelerates atherosclerosis in apolipoprotein E-deficient mice. Circulation 2004, 109:2801-2806.

4. Lalla E, Lamster Lb, Hofmann MA, Bucciarelli L, Jerud AP, Tucker S, Lu Y, Papapanou PN, Schmidt AM: Oral infection with a periodontal pathogen accelerates early atherosclerosis in apolipoprotein E-null mice. Arterioscler Thromb Vasc Biol 2003, 23:1405-1411.

5. Li L, Messas E, Batista EL Jr, Levine RA, Amar S: Porphyromonas gingivalis infection accelerates the progression of atherosclerosis in a heterozygous apolipoprotein E-deficient murine model. Circulation 2002, 105:861-867.

6. Loos BG, Craandijk J, Hoek FJ, Wertheim-van Dillen PM, van der Velden U: Elevation of systemic markers related to cardiovascular diseases in the peripheral blood of periodontitis patients. J Periodontol 2000, 71:1528-1534

7. Slade GD, Offenbacher S, Beck JD, Heiss G, Pankow JS: Acute-phase inflammatory response to periodontal disease in the US population. J Dent Res 2000, 79:49-57.

8. Noack B, Genco RJ, Trevisan M, Grossi S, Zambon JJ, De Nardin E: Periodontal infections contribute to elevated systemic C-reactive protein level. J Periodontol 2001, 72:1221-1227.

9. Deshpande RG, Khan MB, Genco CA: Invasion of aortic and heart endothelial cells by Porphyromonas gingivalis. Infect Immun 1998, 66:5337-5343.

10. Dorn BR, Dunn WA Jr, Progulske-Fox A: Invasion of human coronary artery cells by periodontal pathogens. Infect Immun 1999, 67:5792-5798.

11. Amar S, Gokce N, Morgan S, Loukideli M, Van Dyke TE, Vita JA: Periodontal disease is associated with brachial artery endothelial dysfunction and systemic inflammation. Arterioscler Thromb Vasc Biol 2003, 23:1245-1249.

12. Mercanoglu F, Oflaz H, Oz O, Gökbuget AY, Genchellac H, Sezer M, Nişanci Y, Umman S: Endothelial dysfunction in patients with chronic periodontitis and its improvement after initial periodontal therapy. J Periodontol 2004, 75:1694-1700.

13. Seinost G, Wimmer G, Skerget M, Thaller E, Brodmann M, Gasser R, Bratschko RO, Pilger E: Periodontal treatment improves endothelial dysfunction in patients with severe periodontitis. Am Heart J 2005, 149:1050-1054.

14. Elter JR, Hinderliter AL, Offenbacher S, Beck JD, Caughey M, Brodala N, Madianos PN: The effects of periodontal therapy on vascular endothelial function: a pilot trial. Am Heart J 2006, 151:47.

15. Higashi Y, Goto C, Jitsuiki D, Umemura T, Nishioka K, Hidaka T, Takemoto H, Nakamura S, Soga J, Chayama K, Yoshizumi M, Taguchi A: Periodontal infection is associated with endothelial dysfunction in healthy subjects and hypertensive patients. Hypertension 2008, 51:446-453.

16. Lopez JA, Armstrong ML, Piegors DJ, Heistad DD: Effect of early and advanced atherosclerosis on vascular responses to serotonin, thromboxane $A_{2}$ and ADP. Circulation 1989, 79:698-705.

17. Suwaidi JA, Hamasaki S, Higano ST, Nishimura RA, Holmes DR Jr, Lerman A: Long-term follow-up of patients with mild coronary artery disease and endothelial dysfunction. Circulation 2000, 101:948-954.

18. Schächinger V, Britten MB, Zeiher AM: Prognostic impact of coronary vasodilator dysfunction on adverse long-term outcome of coronary heart disease. Circulation 2000, 101:1899-1906.

19. Perticone F, Ceravolo R, Pujia A, Ventura G, lacopino S, Scozzafava A, Ferraro A, Chello M, Mastroroberto P, Verdecchia P, Schillaci G: Prognostic significance of endothelial dysfunction in hypertensive patients. Circulation 2001, 104:191-196
20. Heitzer T, Schlinzig T, Krohn K, Meinertz T, Münzel T: Endothelial dysfunction, oxidative stress, and risk of cardiovascular events in patients with coronary artery disease. Circulation 2001, 104:2673-2678.

21. Gokce N, Keaney JF Jr, Hunter L, Watkins MT, Menzoian JO, Vita JA: Risk stratification for postoperative cardiovascular events via noninvasive assessment of endothelial function: a prospective study. Circulation 2002, 105:1567-1572.

22. Vita JA, Keaney JF Jr: Endothelial function: a barometer for cardiovascular risk? Circulation 2002, 106:640-642.

23. Baker PJ, Evans RT, Roopenian DC: Oral infection with Porphyromonas gingivalis and induced alveolar bone loss in immunocompetent and severe combined immunodeficient mice. Arch Oral Biol 1994, 39:1035-1040.

24. Donovan J, Brown P: Blood collection. Curr Protoc Immunol 2006, Chapter 1(Unit 1.7).

25. Horne BD, Anderson $\mathrm{JL}$, John JM, Weaver A, Bair TL, Jensen KR, Renlund DG, Muhlestein JB, Intermountain Heart Collaborative Study Group: Which white blood cell subtypes predict increased cardiovascular risk? J Am Coll Cardiol 2005, 45:1638-1643.

26. Nogueira BV, Peotta VA, Meyrelles SS, Vasquez EC: Evaluation of aortic remodeling in apolipoprotein E-deficient mice and renovascular hypertensive mice. Arch Med Res 2007, 38:816-821.

27. Piedrahita JA, Zhang SH, Hagaman JR, Oliver PM, Maeda N: Generation of mice carrying a mutant apolipoprotein $\mathrm{E}$ gene inactivated by gene targeting in embryonic stem cells. Proc Natl Acad Sci USA 1992, 89:4471-4475.

28. Plump AS, Smith JD, Hayek T, Aalto-Setälä K, Walsh A, Verstuyft JG, Rubin EM, Breslow JL: Severe hypercholesterolemia and atherosclerosis in apolipoprotein E-deficient mice created by homologous recombination in ES cells. Cell 1992, 71:343-353.

29. Zhang SH, Reddick RL, Piedrahita JA, Maeda N: Spontaneous hypercholesterolemia and arterial lesions in mice lacking apolipoprotein E. Science 1992, 258:468-471.

30. Zhang SH, Reddick RL, Burkey B, Maeda N: Diet-induced atherosclerosis in mice heterozygous and homozygous for apolipoprotein $\mathrm{E}$ gene disruption. J Clin Invest 1994, 94:937-945.

31. Jawień J, Nastałek P, Korbut R: Mouse models of experimental atherosclerosis. J Physiol Pharmacol 2004, 55:503-517.

32. Ross R: Atherosclerosis - an inflammatory disease. N Engl J Med 1999, 340:115-126.

33. Miyamoto T, Yumoto H, Takahashi Y, Davey M, Gibson FC, Genco CA: Pathogen-accelerated atherosclerosis occurs early after exposure and can be prevented via immunization. Infect Immun 2006, 74:1376-1380.

34. Brodala N, Merricks EP, Bellinger DA, Damrongsri D, Offenbacher S, Beck J, Madianos P, Sotres D, Chang YI, Koch G, Nichols TC: Porphyromonas gingivalis bacteremia induces coronary and aortic atherosclerosis in normocholesterolemic and hypercholesterolemic pigs. Arterioscler Thromb Vasc Biol 2005, 25:1446-1451.

35. Gimbrone MA Jr: Endothelial dysfunction and atherosclerosis. J Card Surg 1989, 4:180-183.

36. Villeneuve N, Fortuno A, Sauvage M, Fournier N, Breugnot C, Jacquemin C, Petit C, Gosgnach W, Carpentier N, Vanhoutte P, Vilaine JP: Persistence of the nitric oxide pathway in the aorta of hypercholesterolemic apolipoprotein-E-deficient mice. J Vasc Res 2003, 40:87-96.

37. Bonthu S, Heistad DD, Chappell DA, Lamping KG, Faraci FM: Atherosclerosis, vascular remodeling, and impairment of endotheliumdependent relaxation in genetically altered hyperlipidemic mice. Arterioscler Thromb Vasc Biol 1997, 17:2333-2340.

38. Crauwels HM, Van Hove CE, Holvoet P, Herman AG, Bult H: Plaqueassociated endothelial dysfunction in apolipoprotein E-deficient mice on a regular diet. Effect of human apolipoprotein Al. Cardiovasc Res 2003, 59:189-199.

39. Ohashi M, Runge MS, Faraci FM, Heistad DD: MnSOD deficiency increases endothelial dysfunction in ApoE-deficient mice. Arterioscler Thromb Vasc Biol 2006, 26:2331-2336.

40. Matsumoto T, Miyamori K, Kobayashi T, Kamata K: Apocynin normalizes hyperreactivity to phenylephrine in mesenteric arteries from cholesterolfed mice by improving endothelium-derived hyperpolarizing factor response. Free Radic Biol Med 2006, 41:1289-1303. 
41. Gödecke A, Ziegler M, Ding Z, Schrader J: Endothelial dysfunction of coronary resistance vessels in apoE-/- mice involves NO but not prostacyclin-dependent mechanisms. Cardiovasc Res 2002, 53:253-262.

42. Xu X, Gao X, Potter BJ, Cao JM, Zhang C: Anti-LOX-1 Rescues Endothelial Function in Coronary Arterioles in Atherosclerotic ApoE Knockout Mice. Arterioscler Thromb Vasc Biol 2007, 27:871-877.

43. Morikawa K, Matoba T, Kubota H, Hatanaka M, Fujiki T, Takahashi S, Takeshita A, Shimokawa H: Influence of diabetes mellitus, hypercholesterolemia, and their combination on EDHF-mediated responses in mice. J Cardiovasc Pharmacol 2005, 45:485-490.

44. Arruda RM, Peotta VA, Meyrelles SS, Vasquez EC: Evaluation of vascular function in apolipoprotein E knockout mice with angiotensin-dependent renovascular hypertension. Hypertension 2005, 46:932-936.

45. Cola MS, Gava AL, Meyrelles SS, Vasquez EC: Endothelial dysfunction of resistance vessels in female apolipoprotein E-deficient mice. Lipids Health Dis 2010, 9:51.

46. Fujioka D, Nakamura S, Yoshino H, Shinohara H, Shiba H, Mizuno N, Hasegawa N, Shindoh N, Uchida Y, Ogawa T, Kawaguchi H, Kurihara H: Expression of endothelins and their receptors in cells from human periodontal tissues. J Periodontal Res 2003, 38:269-275.

47. Ivey ME, Osman N, Little PJ: Endothelin-1 signalling in vascular smooth muscle: pathways controlling cellular functions associated with atherosclerosis. Atherosclerosis 2008, 199:237-247.

doi:10.1186/1476-511X-10-80

Cite this article as: Pereira et al:: Oral $P$. gingivalis infection alters the vascular reactivity in healthy and spontaneously atherosclerotic mice. Lipids in Health and Disease 2011 10:80.

\section{Submit your next manuscript to BioMed Central} and take full advantage of:

- Convenient online submission

- Thorough peer review

- No space constraints or color figure charges

- Immediate publication on acceptance

- Inclusion in PubMed, CAS, Scopus and Google Scholar

- Research which is freely available for redistribution

Submit your manuscript at www.biomedcentral.com/submit
Biomed Central 